\title{
Translation of the European Arrest Warrant in the Light of Intercultural Communication
}

\section{Przekład europejskiego nakazu aresztowania w świetle komunikacji interkulturowej}

\author{
Grażyna Bednarek \\ Katedra Lingwistyki Stosowanej, Wyższa Szkoła Gospodarki \\ 85-229 Bydgoszcz, ul. Garbary 2 \\ g.bednarek@neostrada.pl
}

\begin{abstract}
The aim of this paper is to examine translation of the European arrest warrant in the light of intercultural communication. The paper consists of three parts. The first part addresses major aspects of judicial cooperation in criminal matters within the territory of the European Union (EU) and introduces the European arrest warrant (EAW) as one of the major legal instruments of such cooperation. The second part focuses on the notion of legal translation as an act of intercultural communication. The third part illustrates, via translation of the European arrest warrant, how certain differences between the two most important legal families of the world, the Common Law and the Civil Law, influence the process of intercultural communication.
\end{abstract}

1. Major aspects of judicial co-operation in criminal matters within the territory of the European Union: introduction of the European arrest warrant

On 21 September 2001, the European Council met in an extraordinary session to analyze the international situation in the wake of the disastrous and deadly terrorist attacks in the United States (cf. Conclusions and Plan of Action of the Extraordinary European Council Meeting at http://www.consilium.europa.eu/ueDocs/cms_Data/docs/pressData/en/ec/140.en.pdf).

Under Article 2 of the Conclusions and Plan of Action of the Extraordinary European Council Meeting related to the European Policy to Combat Terrorism, the European Council approved the plan of enhanced police and judicial cooperation and announced its agreement to introduce a European arrest warrant.

Hence, many assume that introduction of the European arrest warrant was an immediate outcome of the said European Council meeting, while the necessity to reform the extradition procedures was recognized 20 years ago (Gilmore 2002: 144).

The beginnings of judicial cooperation in EU date back to 1-2 December 1975, when the Ministers of Interior met in Rome with a view to combat terrorism, radicalism, extremism and international violence (Terrorisme, Radicalisme, 
Extremisme, Violonce Internationale), the so-called TREVI Group, that met twice a year until 1993 when it was substituted for the meetings of European Council for Justice and Home Affairs (JHA) (Hofmański et al. 2008: 19).

The abolition of checks at the internal borders and creation of a single external border under the Schengen Agreement of 14 June 1985 and Schengen Convention of 19 June 1990, which came into effect in March 1995, facilitated criminals' operational mobility and entailed the undesired consequence of the increased transnational crime (Fennelly 2007: 521).

To counterbalance free movement of persons in EU and to guarantee security within the territory of the Schengen States, the Schengen Convention included the so-called "compensatory measures", e.g.: the strengthening of judicial cooperation and mutual assistance in criminal matters, mutual assistance for the purposes of preventing and detecting criminal offences, creation of the Schengen Information System (SIS), faster extradition procedures (cf. Schengen Acquis Official Journal of European Union 22.2000: p. 435).

The Treaty on European Union (TEU) signed on 1 February 1992 in Maastricht, which came into effect on 1 November 1993, established judicial cooperation in criminal matters under the III pillar (JHA) (Hofmański et al. 2008: 21).

Under the Amsterdam Treaty signed on 2 October 1997, which entered into force on 1 May 1999, Title VI - Provisions on Police and Judicial Cooperation in Criminal Matters, the Union's objective was formulated as follows:

"to provide citizens with a high level of safety within an area of freedom, security and justice by developing common action among Member States in the field of police and judicial cooperation in criminal matters..." (cf. OJ C 340 of 10 November 1997)

The Tampere European Council of 15-16 October 1999 reiterated the significance of the Union as the area of freedom, security and justice, however, its novelty relates to mutual recognition of judicial decisions under article 33 (Gilmore 2002: 144):
"Enhanced mutual recognition of judicial decisions and judgments and the necessary approximation of legislation would facilitate cooperation between authorities and the judicial protection of individual rights. The European Council therefore endorses the principle of mutual recognition which, in its view, should become the cornerstone of judicial cooperation in both civil and criminal matters within the Union. The principle should apply to judgments and to other decisions of judicial authorities."

The Tampere Conclusions also urged to undertake steps with reference to extradition:

"With respect to criminal matters, the European Council urges Member States to speedily ratify the 1995 and 1996 EU Conventions on extradition. It considers that the formal extradition procedure should be abolished among the Member States as far as persons are concerned who are fleeing from justice after having been finally sentenced, and replace by a simple transfer of such persons, in compliance with Article 6 TEU. Consideration should also be given to fast track extradition procedures, without prejudice to the principle of fair trial. The European Council invites the Commission to make the proposals on this matter in the light of the Schengen Implementing 


\section{Investigationes Linguisticae, vol. XVII}

Agreement." (cf. Tampere European Council 15 and 16 October

1999, Presidency Conclusions).

The principle of mutual recognition as the cornerstone of judicial cooperation under III pillar is of outstanding significance and the Framework Decision (2002/584/JHA) of 13 June 2002, which introduces the European arrest warrant constitutes an example of its implementation (Hofmański et al. 2008: 28).

The said Framework Decision on the European arrest warrant and the surrender procedures between Member States, replace the following extradition proceedings between Member States: the 1957 European Extradition Convention on the suppression of terrorism, the 1978 European Convention on the suppression of terrorism as regards extradition, the agreement of 26 May 1989 between 12 Member States on simplifying the transmission of extradition requests, the 1995 Convention on the simplified extradition procedure, the 1996 Convention on extradition, the provisions of the Schengen agreement (cf. Framework Decision 2002/584/JHA (4)).

The Framework Decision defines the European arrest warrant in Chapter 1(1) as:

"[...] a judicial decision issued by a Member State with a view to arrest and surrender by another Member State of a requested person, for the purposes of conducting a criminal prosecution or executing a custodial sentence or detention order."

Pursuant to Chapter 1, Article 1, Paragraph 2 of the said Framework Decision:

"Member States shall execute any European arrest warrant on the basis of the principle of mutual recognition and in accordance with the provisions of this Framework Decision."

A European arrest warrant may be issued for acts punishable by the law of the issuing Member State by a custodial sentence or a detention order for a maximum period of at least 12 months or, where a sentence has been passed or detention order has been made, for sentences of at least four months (cf. Framework Decision (2002/584/JHA Art. 2(1)).

The list of 32 offences giving rise to surrender pursuant to the European arrest warrant includes, inter alia: participation in a criminal organization, terrorism, corruption, forgery of means of payment, sexual exploitation of children and child pornography, illicit trafficking in narcotic drugs and psychotropic substances, murder, grievous bodily injury, counterfeiting and piracy of products (cf. Framework Decision 2002/584/JHA Art. 2(2)) .

The innovative character of the European arrest warrant is attributed to: (1) its judicial nature, (2) partial abolition of double criminality check with reference to the thirty two offences listed, i.e., the rule that an offence must be punishable both in the country, where the requested person is located and in the country issuing the warrant, (3) simplification and acceleration of the surrender procedures, (4) surrender of the requested person under the principle of mutual recognition and mutual trust, (6) independence of the requested person's surrender from his/her nationality (Gilmore 2002: 145-147; Hofmański et al. 2008: 56-57; Pérignon, Daucé 2006: 205-208).

Article 8 of the Framework Decision defines the content and form of the European arrest warrant, which must contain the identity and nationality of the requested person, the name, address, telephone and fax numbers and e-mail address of the issuing judicial authority, evidence of enforceable judgment, the nature and legal classification of the offence, a description of the circumstances in which the offence was committed, including the time, place and degree of participation in the offence by the requested person, the penalty imposed, if there 
is a final judgment, or the prescribed scale of penalties for the offence under the law of the issuing Member State.

The European arrest warrant must be translated into the official language or one of the official languages of the executing Member States.

\section{The notion of legal translation as an act of intercultural communication}

For the purposes of this paper translation of the European arrest warrant is understood as an act of intercultural communication.

The evolution of translation understood as a static linguistic phenomenon to an act of intercultural communication materialized in the 1980s (Snell-Hornby 1988: 43; Pisarska 1996: 26; Munday 2001: 87; Snell-Hornby 2006: 51-55).

Snell-Hornby (1988: 43) speaks of three new approaches introduced in Germany in the 1980s: Hönig and Kussmaul 1982, Reiss and Vermeer 1984 and Hölz-Mänttari 1984.

Hönig and Kussmaul in Strategie der Übersetzung (1982) delineate the notion of text understood as an integral part of a sociocultural background and stress the significance of the function of a translation (Snell-Hornby 1988: 45). For them, translation is dependent on its function as a text embedded in the target culture and the translator may either preserve the original function of the source text in its own culture (Funktzionskonstanz) or change the function to adapt to specific needs in the target culture (Funktzionsveränderung) (Snell-Hornby 1988: 44). Vermeer in the book, which he wrote with Katharina Reiss Grundlegung einer allgemeinen Translationstheorie (1984), emphasizes that language is not an autonomous system, but is part of a culture. In his view, the translator should not only be bilingual, but also bicultural (Snell-Hornby 2006: 52). In his lecture given in Zurich on 21 May 1984, published as "Translation as a cultural transfer" Vermeer (1986: 33) defines translation as:

"[...] an offer of information in a language $t$ of the culture $\mathrm{T}^{1}$, which imitates an offer of information in a language $s$ of the culture $\mathrm{S}$ according to specified function. In other words, a translation is not transcoding of words or sentences from one language to another, but a complex form of action in which someone gives information about a text (source language material) under new functional and linguistic conditions and in a new situation, while preserving formal aspects as far as possible."

His explanation of translation abandons the linguistic definition of translation dominant at the time and provided by Koller:

"In linguistic terms translation can be described as transcoding or substitution; elements a1, a2, a3... of the language system L1 are replaced by elements b1, b2, b3... of the language system L2" (Koller 1972: 69-70 as cited by Snell-Hornby 2006: 53-54 ).

The most important aspect of Vermeer's translation theory is the skopos (Greek word for 'aim" or 'purpose'). According to skopos theory the major principle determining any translation process is the purpose (skopos) of the overall translational action (Vermeer 1996: 15; Pisarska 1996: 27; Nord 1997: 27; Munday 2001: 79; Snell-Hornby 2006: 51).

Vermeer explains the skopos rule in the following way: 


\section{Investigationes Linguisticae, vol. XVII}

"Each text is produced for a given purpose and should serve this purpose. The skopos rule thus reads as follows: translate/interpret/speak/write in a way that enables your text/translation to function in the situation in which it is used and with the people who want to see it and precisely in the way they want it to function." (Vermeer 1989a: 20 as cited by Nord 1997: 29).

The skopos theory is part of the theory proposed by Hölz-Mänttari who defines translation as an act of communication across cultural barriers. Hölz-Mänttari who presented her theory of translation in Translatorisches Handeln. Theorie und Methode (1984), reduces the status of the source text (Snell-Hornby 2006: 57) similarly to Vermeer, who spoke of "de-throning of the source text" (Snell-Hornby 2006: 54). In her theory, she declines the notion of "text" and introduces the notion of "message" (Botschaft). Since both Vermeer and Hölz-Mänttari view translation as a cultural transfer rather than linguistic, in which language is part of the culture (Snell-Hornby 2006: 54), it follows that the concept of culture is essential for the functional approach to translation. The concept of culture accepted by Vermeer is that of Heinz Göring's, which in turn is based on the that of the American ethnologist Ward Goodenough (Snell-Hornby 2006: 54; Nord 2001: 33):

"Culture consists of everything one needs to know, master and feel, in order to assess where members of a society are behaving acceptably or deviantly in their various roles, and in order to behave in a way that is acceptable or deviant for that society, as far as one wishes to do so and is not prepared to take the consequences arising from deviant conduct." (Göring 1977: 10, as cited by Snell-Hornby 2006: 55 ).

Nord (1997: 33) emphasizes that Vermeer's own definition of culture concentrates even more on norms and conventions:

"[culture is] the entire setting of norms and conventions an individual as a member of his society must know in order to be 'like everybody' - or to be able to be different from everybody". (Vermeer 1987a: 28)

The concept of culture understood as a totality of knowledge, norms and conventions is essential to the functional approach of translation as a form of communication and social action as opposed to abstract code-switching and was later broadened by Heidrun Witte (Snell-Hornby 2006: 55).

As regards Chrsitiane Nord, similarly to the theories above, her concept of translation is as she indicates "basically functional" and the notion of "function" is the primary criterion for the process of translation (Nord 2005: 5).

Her model for translation-oriented text analysis contributes profoundly to understanding of the intercultural text transfer. As expounded by the author, a model of source-text analysis, which may be applied to all types of texts not only facilitates understanding of the function of the elements or features in the content and structure of the source text as a communicative occurrence, but also allows the translator to choose the suitable translation strategies for the intended purpose of the particular translation (Nord 2005: 5).

To summarize the functionalist translation theories, it must be indicated that in contrast to the linguistic theories of translation, which saw translation as a static phenomenon, an activity merely between languages, a linguistic transfer 


\section{Grażyna Bednarek: Translation of the European Arrest \\ Warrant in the Light of Intercultural Communication}

based on the process of transcoding, the functionalist approach to translation is culture oriented, is oriented towards the function of the target text, proclaims dethroning of the source text, views texts as an integral part of the world, not an isolated specimen of language, and finally, as stated above, understands translation as an act of cross-cultural communication (Snell-Hornby 1988: 38).

As regards legal translation, Šarčević (1997: 55) and Cao (2006: 5) too define legal translation as an act of communication.

However, although one must acknowledge the profound impact of the functionalist approach to translation studies in general, which as shown above transformed the very meaning of the translation process, the present author wishes at this point to present vital aspects of legal translation and explain why certain facets of the functionalist approach may not be applied to legal translation.

As indicated by Šarčević (1997: 12) and Cao (2006: 7) legal translation is a specialized area of translational activity due to the fact that it involves law and entails not only linguistic, but also legal consequences.

Bearing this in mind, translation of legal texts is regarded as a double operation implying both interlingual and legal transfer (Constantinescu 1974: 147 as cited by Šarčević 1997: 12).

In addition, the normative function and authority of the legal texts makes legal texts special and entails significant consequences for legal translation (Šarčević 1997: 11; Cao 2006: 10).

Let us have a closer look at the typology of legal texts as presented by Šarčević (1997) and Cao (2006) to understand the nature of legal documents in the first place.

Šarčević (1997: 11) divides legal texts into the following three groups according to their function: 1) primarily prescriptive, 2) primarily descriptive but also prescriptive, 3) purely descriptive. The first group includes laws and regulations, codes, contracts, treaties and conventions, and as indicated by Šarčević, they are normative texts which prescribe a specific course of action. The second group of legal texts consists of hybrid texts, which are primarily descriptive but also include prescriptive parts. These include judicial decisions and instruments used to carry on judicial and administrative proceedings such as actions, pleadings, briefs, requests, petitions. The third group contains purely descriptive texts written by legal scholars, like legal opinions, law textbooks, articles.

Cao (2006: 9-10) distinguishes the following categories of legal texts: 1) legislative texts, i.e., domestic statutes and subordinate laws, international treaties and multilingual laws, and other laws produced by lawmaking authorities, 2) judicial texts produced in the judicial process by judicial officers and other legal authorities, 3) legal scholarly texts produced by academic lawyers or legal scholars in scholarly works and commentaries, 4) private legal texts including texts written by lawyers, e.g. contracts, leases, wills, litigation documents, and texts written by non-lawyers, e.g. private agreements, witness statements and other documents produced by non-lawyers and used in litigation and other legal situations.

From the enumerated variants of legal texts it follows that legal translation refers to the translation of the texts used in law and legal settings.

The vast majority of the named legal texts are normative in character as stated above, that is they prescribe commands and prohibitions, grant permission and power, create obligations and rights (Cornu 1990: 264; 267). 


\section{Investigationes Linguisticae, vol. XVII}

How does that compare with the functionalist approach to translation studies? Why may certain aspects of the functionalist approach to translation not be applied to legal translation?

Firstly, as indicated by Hönig and Kußmaul (1982) text is understood as an integral part of the sociocultural background and its function is of primary importance, the translator, as they say, may either preserve the original function of the source text (Funktionskonstanz) or change the function of the source text (Funktzionsveränderung).

As regards legal translation, there is no doubt that the text is a communicative occurrence (de Beaugrande and Dressler 1981: 3) and as stated above it belongs to a given sociocultural background. However, in case of legal translation, the legal translator may not change the function of the source text, because the legal translator's role is to produce a text that is equal in meaning and effect to the source text. It is impossible to change the function of the target text, because the legal translator is bound by the principle of fidelity to the source text for preserving the letter of law (Šarčević 1997: 16).

In case of the European arrest warrant translation, for instance, the function of the source text may by no means be changed, because under Framework Decision of 13 June 2002, the European arrest warrant is a judicial decision and the legal translator is bound by the fidelity to the source text while translating the document for the sake of preserving the letter of law.

As indicated by Šarčević (1997: 16), even when the legal translators won the right to produce the texts in the spirit of the target language, the general indications and guidelines still pointed to fidelity to the source text.

The same has been underlined by Herbot (1987: 822 as cited by Šarčević 1997: 72) the translator is obliged to produce a translation with "the same legal signification":

"Le text d'arrivée doit avoir la même signification juridique

(c'est-a-dire qu'il aura le meme consequences en droit) que le texte de depart."

With reference to Vermeer's skopos theory of translation, there are certain aspects, which may not be applied to legal translation either and here is why.

Firstly, Vermeer's skopos theory, as indicated above, treats translation as an intercultural transfer (Nord 1997: 11, 34), whereas it must be remembered that in case of legal translation, the transfer is not only intercultural, but primarily legal (Constantinesco 1974: 147 as cited by Šarčević 1997: 12; Groot de 1987: 5).

Secondly, Vermeer's translation theory regards the source and the target text as "an offer of information" (Vermeer 1982 as cited by Nord 1997: 12), which in case of normative legal texts is not applicable, because if both the source and target texts are normative in nature they are more than a source of information, that means they must be duly executed.

Thirdly, Vermeer's theory of translation de-thrones the source text (SnellHornby 2006: 54), which in the view of the present author should not be done. The significance of the source text for legal translation is profound, if the legal significance of the target text is to be the same.

Thus, if the target text of a European arrest warrant as a judicial decision is to produce the same legal effect as the source text, it is advisable to conduct a careful analysis of the source text bearing in mind that it is an example of both intercultural and legal transfer, which as explained by Nord (2005: 24) shall enable the translator to establish the actual function-in-culture of a source text and 


\section{Grażyna Bednarek: Translation of the European Arrest \\ Warrant in the Light of Intercultural Communication}

compare it with the function-in-culture of the target text required by the initiator and enable him/her to choose the best translation method.

In addition, following Vermeer (1996: 15), there is a skopos for each translational act and different skopoi lead to different translations of the same source text. As explained by Reiss and Vermeer (1984: 139) the demand for fidelity is subordinated to the skopos, so if the skopos requires a change of function, the required standard of fidelity to the source text is not applied, the translator is then bound by appropriateness to the particular skopos. This, however, does not hold true for legal translation, where the skopos of the target text is exactly the same as that of the source text.

So, by way of illustration, if the European arrest warrant is a type of legal text of normative character issued by a EU Member State with a view to the arrest and surrender by another Member State of a requested person for the purposes of conducting a criminal prosecution or executing a custodial sentence or detention order, then, due to its normative character its function in the target text must be preserved.

Moreover, the translation of the European arrest warrant must be done by a sworn translator, who is bound by the code of ethics of a sworn translator, which clearly defines the principles of an authenticated translation including the aspects of legal translation stated above, so any alterations to the texts are strictly forbidden (cf. Code of Conduct of a Sworn Translator with a Commentary issued by TEPIS 2007).

Finally, in case of translation of legal texts of normative character, the translation once vested with the force of law, or authenticated may not be referred to as translation, but must be treated as an equally authentic, parallel, legal text (Šarčević 1997: 20, 64); Wagner 2002: 1, 7-9; Doczekalska 2009: 117), hence, as stated above, any amendments to the source text may only be done by its author, in case of the European arrest warrant, it may be done by a judge of a Regional Court in Poland, let alone the fact that such alterations must be indicated in the contents of the document together with the reasons and date of amendment.

As further indicated by Šarčević, despite the fact that Vermeer's theory refers to all types of texts (Vermeer 1982: 99 as cited by Šarčević 1997: 18), Vermeer failed to convince the LSP translators that his theory was applicable to special purpose texts, because specialists in LSP translations insisted that the primary goal of LSP translators was to transfer the meaning or the message of the source text as precisely as possible (Fluck 1985: 136; Gémar 1995-II: 115 as cited by Šarčević 1997: 18).

In addition, as emphasized by Šarčević (1997: 19), in claiming that the translation strategy of legal translation can be determined on the function of the target text alone, Vermeer failed to take account of legal criteria, while selecting the appropriate translation strategy, since as regards contracts, for example, the choice of translation strategy depends on the law governing the contract, viz., the contract may either be interpreted to the source or target legal system and in terms of linguistics, this identifies the system of reference, that is, whether the signs in the target text refer to objects and concepts in the source or the target legal system.

To summarize the discussion of the applicability of the functionalist approach to legal translation, it must be emphasized that the contribution of the functionalist approach for the discipline of translation studies in general is vital and unquestionable. 


\section{Investigationes Linguisticae, vol. XVII}

There is no doubt that the definition of translation gained a new image of a dynamic, bicultural, target oriented communicative event.

Although, as shown above, certain aspects of the functionalist approach cannot be accepted to legal translation, because "on ne peut pas se permettre de traduire une loi comme on traduit un autre texte, car la traduction est aussi loi" (Legault 1977: 19).

Having established the undeniable influence of the functional approach on the discipline of translation studies and explaining how legal translation may benefit from this approach and what facets of the said approach may not be applied to legal translation, in what follows the present author wishes to point out some major implications of the European arrest warrant translation in the light of intercultural communication.

However, before the analysis begins, let us first have a closer look at the study of communication studies.

Fiske (1990: 2) defines communication as social interaction through messages. Communication, as he points out, is central to the life of our culture, and without communication any culture dies.

There are two main schools in the study of communication (Fiske 1990: 23). The first, which perceives communication as the transmission of messages, is concerned with how senders and receivers encode and decode the messages, how the transmitters use the channels and media of communication, which defines communication as a process by which one person affects the behaviour of or state of mind of another. The second, delineates communication as the production and exchange of meanings. It deals with how messages, or texts, interact with people in order to produce meanings; that is it is concerned with the role of texts in our culture. For this school, the study of communication is the study of text and culture and the main study is semiotics. Each of the mentioned schools interprets the definition of communication as social interaction through messages in its own way. For the first one social interaction is the process by which one person relates to others, or affects the behaviour, state of mind or emotional response of another. The school of semiotics understands social interaction as that which constitutes the individual as a member of a particular culture and society.

As further explained by Fiske (1990: 3) each of the schools has a different understanding of what constitutes a message. The first one defines a message as that which is transmitted by the communication process with intention as its underlying factor. Semiotics, on the other hand sees a message as a construction of signs, which through interacting with receivers, produce meanings.

It has on many occasions been established that translation in general is a communicative event taking place in a communicative situation (Nord 1997: 17; Nord 2005: 13; Snell-Hornby 2006: 54).

As such, it differs from any ordinary communicative event, because it entails participation of two cultures, two languages. In such a communicative situation, the source and target texts are part of a communicative act.

As emphasized by Nord (2005: 14) the prerequisite for such a communicative event is the existence of a situation in a given time and space, and participants wishing to communicate for a certain purpose by means of a text.

The text understood as "the totality of communicative signals used in a communicative interaction (Kallmeyer et al. as cited by Nord 2005: 16) has a function and is transmitted via a channel. 


\section{Grażyna Bednarek: Translation of the European Arrest \\ Warrant in the Light of Intercultural Communication}

The model of communication developed for the purpose of translation by Sager (1994: 93) distinguishes between several functional agents participating in the act of communication: producers of texts and massages, communication agents, i.e., senders of texts, recipients of texts and messages and mediators, i.e., translators.

Under the said theory of communication, the message is encoded in a system of signs (Sager 1994: 94-96).

As emphasized by Šarčević (1997: 56), "legal communication can be effective only if interaction is achieved between text producers and receivers".

Who are the participants of the process of intercultural communication with regard to translation of the European arrest warrant?

The procedures relating to issuing and execution of the European arrest warrants have been stipulated in the Polish Code of Criminal Procedure (cf. http://www.law.uj.edu.pl/ kpk/eaw/legislation/Poland_National_legislation_EA W.pdf).

Under chapter 65a of the Code of Criminal Procedure on requesting EU Member States for surrender of prosecuted persons on the basis of a EAW and 65b requests from EU Member States for surrender of prosecuted persons on the basis of a EAW the participants of the intercultural communication process in the aspect of the European arrest translation include as follows:

Firstly, the text producer, a Judge of a Regional Court in Poland, a representative of a judicial authority responsible for production of the EAW. On the official request of the Regional Public Prosecutor, a Judge of a Regional Court fills out the EAW form in the Polish language, which relates to a given person who had committed an offence, referred to, under the mentioned above Framework Decision, as "requested person".

Secondly, under article 607c $\S 2$ a Warrant should be translated into an official language of the executing state. All the official documents must in Poland be translated by a sworn translator. The profession of the sworn translator is regulated under Act of 25 November of 2004 (cf. Official Journal No. 273, item 2702).

The sworn translator is sent the EAW original in the Polish language together with the translation brief, which is a decision of a Judge of a Regional Court appointing the sworn translator for the task of conducting the translation of the EAW.

The translation brief includes the following information: the name of the Judge of the Regional Court who appoints the sworn translator for translation of the EAW and the name of the Court Clerk, the name of the Public Prosecutor at whose request the EAW is issued, the name of the requested person, the name of his parents, name and number of his identity card or passport, place of residence, if available. The Judge states the reasons why a given EAW must be issued, that is, $\mathrm{s} /$ he describes what offence or offences were committed by the requested person. The committed offences relate to specific articles of the Penal Code which must be pointed out. In addition, the translation brief includes the date of expiry of the statute of limitation. The reason, which impacts directly the issue of the EAW is the fact that the requested person, which committed an offence wishes to evade justice and is sought after abroad in the territory of the European Union on the basis of the EAW. Finally, the translation brief includes the deadline by which the translation must be returned. 


\section{Investigationes Linguisticae, vol. XVII}

The translated EAW is then returned to the Regional Court and is sent to a specific EU Member State judicial authority, in cases when the place of residence of the requested person has been established, if not, the data from the European arrest warrant are put into the Schengen Information System, which is supposed to facilitate the establishment of the place of residence of the requested person and next his/her detention, temporary arrest and execution of the EAW and finally his/her extradition to Poland.

The judicial authority of the EU Member State which receives the translated EAW plays the role of the immediate target text receiver. The role of the target text receiver as the judicial authority responsible for the execution of the EAW is regulated by the Framework Decision and involves the hearing of the requested person under Article 14.

The Translation of the EAW in this case, as explained above may not be referred to as translation, it performs the function of the judicial decision in the foreign language and is subject to execution. Hence it must be considered as a parallel legal text.

The role of the translator in the process of the intercultural and legal transfer is twofold. First, s/he is the mediator who bridges the gaps between two legal cultures. Secondly, s/he plays the role of the author of the target text.

The role of the author of the legal text is subject to a number of constraints accompanying the process of translation, which constitute the final part of this paper.

\section{Legal, linguistic and cultural constraints in the translation of the EAW}

For the purposes of this paper, major implications relating to translation of the European arrest warrant refer to: (1) different legal systems and laws, (2) linguistic differences, (3) cultural differences.

Cao (2007: 23) stresses that "law and legal language are system-bound, that is, they reflect the history, evolution and culture of a specific system". "Legal language is not a universal technical language but one that is tied to a national legal system (Weisflog 1987: 203, as cited by Cao 2007: 23).

Under Article 8 of the Framework Decision, all Member States adopted an identical form and content of the European arrest warrant, which is attached in Annex 1 to Framework Decision, to quash the diversity relating to legal systems in the EU.

Although, as indicated by Górski and Sakowicz (2005) and Hofmański et al. (2008) the European integration of Member States and unification of law in the European Union for the purposes of an accelerated surrender of the requested persons, the translator carrying out translation of the European arrest warrant must bear in mind that the expressions used in point (b) devoted to decision on which the warrant is based: "judicial decision" and "enforceable judgment" connote different ideas under two legal families, namely that of the civil and that of the common law.

Zweigert and Kötz (1998: 69) emphasize that:

"The tradition of the English Common Law has been one of gradual development from decision to decision; historically speaking, it is case-law, not enacted law. On the Continent the development since the reception of Roman law has been 
quite different, from the interpretation of Justinian's Corpus Iuris to the codification, nation by nation, of abstract rules. So Common Law comes from the court, Continental law from the study; the great jurists of England were judges, on the Continent professors. On the Continent lawyers, faced with a problem even a new and unforeseen one, ask what solution the rule provides; in England and the United States they predict how the judge would deal with the problem, given the existing decisions".

Hence, one of the challenges the legal translator deals with is the incongruency of legal systems.

Under point (e) of the European arrest warrant, the translator translates the description of the circumstances in which the offence or offences was/were committed. It is under this point, where linguistic implications arise.

As far as the linguistic constraints are concerned, Cao (2007) and Šarčević (1997) attribute linguistic difficulty in legal translation to the absence of equivalent terminology across different languages. De Groot (2006: 424) claims that to achievement of full equivalence in translating the terminology is only possible when the source and target languages relate to the same legal system, which is applicable only in bilingual or multilingual legal systems, like in Belgium, Finland, Switzerland and to a certain degree in Canada.

Despite the fact that under the Framework Decision the EU Member States adopted a common definition of the thirty two offences, the translator is aware of the fact that a definition of a particular offence in the 27 Member States implies different definitions in each State.

Lack of vocabulary equivalence has already been indicated by Humboldt, who stated that:

"No one when he uses a word has in mind exactly the same thing that another has, and the difference, however tiny, sends its tremors throughout language. ... All understanding, therefore, is always at the same time a misunderstanding ... and all agreement of feelings and thoughts is at the same time a means for growing apart." (Humboldt quoted in Cowan 1963, as cited by Jandt 2007: 131).

In his seminal article Why Isn't Translation Impossible Joseph (1998: 86-97) cites Schopenhauer, Schleiermacher, Humboldt, de Saussure who addressed the issue of lack of vocabulary equivalence in their works. For instance, Schleiermacher stated:

"But if one looks at a master's word formations in their totality, at his use of related words and word-roots in a multitude of interrelated writings, how can the translator succeed here, since the system of concepts and their signs in the translator's language is entirely different from that in the original language, and the word-roots, instead of being synchronically identical, cut across each other in the strangest directions. It is impossible, therefore, for the translator's use of one language to be as coherent as that of his author." (Schleiermacher 1813 [1992: 45-46], as cited by Joseph 1998: 86-97). 
By way of illustration, under Article 228 section 1 of the Polish Criminal Code fraud is defined as follows:

"Whoever, with the purpose of gaining a material benefit causes another person to disadvantageously dispose of his own or someone else's property by misleading him, or by taking advantage of a mistake or inability to adequately understand the action undertaken, shall be subject to the penalty of deprivation of liberty for a term of between 6 months and 8 years."

By contrast, under Theft Act 1968 in UK, this offence is defined under Chapter 60 Article 16(2)(c) as follows:

"A person who by any deception dishonestly obtains for himself or another any pecuniary advantage shall on conviction on indictment be liable to imprisonment for a term not exceeding five years."

Attention should be paid to two different expressions in the Polish Criminal Code - the "material benefit" and in the UK Act - the "pecuniary advantage". The UK term implies a monetary advantage, while the Polish term connotes a broader benefit, which may be expressed in pecuniary terms.

Cultural differences are the subsequent source of difficulty. In translation, language should not be regarded as an isolated phenomenon suspended in a vacuum but as integral part of culture, while the text is embedded in a given situation conditioned by its socio-cultural background (Snell-Hornby 1988: 2, as cited by Cao 2006: 31). The strong relationship between language and culture is a well established phenomenon and has on many occasions been underlined (Whorf 1956: 156; 214); Sapir 1966: 16; 69; Hofstede 2001: 21).

Curran (2006: 678) described the characteristics of the language of the law in the following way:

"The language of law is bound to the inner grammar of legal systems, cultures, mentalities, which in turn impede communication in words that are borrowed from another legal system, culture, and mentality."

She also points out that in comparative law translation is often carried out by approximation, so, for example, "the French word 'procès' is generally translated into English as 'trial'. She indicates, however, that certain attributes of 'procès' are not attributes of 'trial'. Hence, similarly, the French or Polish 'judge' is not the English 'judge', the 'cour', or 'sąd' is not the 'court', and last but not least, the French 'jugement', or 'wyrok" is not exactly 'judgment'.

Furthermore, Curran (2006: 711) argues that:

"If law is embedded in culture it may be that the study of law can be undertaken realistically only by adopting the standpoint of someone 'inside' a culture, by a kind of 'immersion' in it. According to this approach, the comparatist must understand law in the same way that people who participate in its culture do. Such a study must recognize the integrity, identity, or coherence of the culture in which law exists, and the interwoven characteristics that make that culture unique and distinguish it from others. [...] Law cocooned inside a culture, it might be claimed, is necessarily different from law that exists in another culture." 
Hence, legal translators must successfully deal with cultural barriers between the SL and TL.

This leads us directly to the implications related to conceptual equivalence, which refers to abstract ideas that may not exist in the same fashion in different languages.

By way of illustration, the word "law", or "judicial decision" connote different ideas in Poland and in the UK, because under the common law, the word "law" refers to the body of case law, based upon judicial decisions and embodied in reports of decided cases, while the "law" as understood by the civil law refers to the enacted law and codes (Zweigert and Kötz 1998: 69).

The translation process has been compared to that of the comparative legal analysis by Bernhard Großfeld, a professor of law (Großfeld 1996: 118-122).

Thus, the translator, similarly to the comparatist lawyer:

"comes across legal institutions, procedures, and traditions

which have no counterpart in the Continental legal world with which he is familiar. At every step he comes across legal institutions, procedures, and traditions which have no counterpart in the Continental legal world with which he is familiar." (Zweigert and Kötz 1998: 181)

The last but not least implication relating to legal translation is that of the choice of an appropriate translation strategy, which for a long time has been a contentious issue.

As indicated by Šarčević, some advocate literal translation for the sake of preservation of the letter of law (Cesana 1910: 5 as cited by Šarčević 1997: 37; Didier 1990: 280, 285, as cited by Šarčević 1997: 16; Weisflog 1987: 191, as cited by Šarčević 1997: 17), while others favour idiomatic translation and creativity (Koutsivitis 1988: 344, as cited by Šarčević 1997: 224).

Although the said issue remains unsolved, "substance must always prevail over form" (Šarčević 1997).

This brings us directly to another issue, namely that of equal effect of the authenticated translations.

Šarčević cites Didier, who claims that "while lawyers cannot expect translators to produce parallel texts which are equal in meaning, they do expect them to produce parallel texts which are equal in legal effect" (Didier 1990: 211, as cited by Šarčević 1997: 71). Hence, as emphasized by Šarčević the role of the translator is to "produce a text that will lead to the same legal effects in practice" (Šarčević 1997: 71).

In view of the above, translation of the European arrest warrant must in practice lead to its execution by competent judicial authorities of the executing EU Member State.

Isabelle Pérignon and Constance Daucé (2007: 203) and Hofmański et al. (2008: 221) claim that the European arrest warrant is considered by the EU Commission to be a growing success story, and the Commission looks forward to strengthening the instrument in the subsequent years. In conclusion of the Report presented by the Commission of European Communities based on Article 34 of the Council Framework Decision of 13 June 2002 on the European arrest warrant and the surrender procedures between Member States of 24 January 2006 we read that: 


\section{Investigationes Linguisticae, vol. XVII}

"despite undeniable initial delay, the European arrest warrant is now operational in most of the cases provided for. Its impact is positive, since the available indicators as regards judicial control, effectiveness and speed are favourable, while fundamental rights are observed."

Hence, it follows that despite certain implications, which the translation of the European arrest warrant entails, the process of intercultural communication so far has been successful.

\section{Bibliography}

Baker, J.H. 2002. An Introduction to English Legal History. Fourth Edition. London: Butterworths.

Cao, D. 2007. Translating Law. Clevedon, [etc.]: Multilingual Matters, cop.

Curran, V. 2006. Comparative Law and Language. in: M. Reimann and R. Zimmermann (Eds.) The Oxford Handbook of Comparative Law. Oxford \& New York: Oxford University Press. pp.675-709.

Doczekalska, A. 2009. Drafting or Translation - Production of Multilingual Legal Texts. in: F. Olsen, A. Lorz, \& D. Stein (Eds.) Translation Issues in Language and Law. Houndmills, Basingstoke, Hampshire: PALGRAVE \& MacMillan.

Gilmore, B. 2002. The EU Framework Decision on the European Arrest Warrant: An Overview from the Perspective of International Criminal Law. ERA-Forum, No. 3, pp. 144-147.

Górski, A., Sakowicz A. 2004. Prawo Karne Procesowe: Europejski nakaz aresztowania nowy instrument Unii europejskiej w walce z przestępczością. Edukacja Prawnicza, $\mathrm{Nr}$ 4(61), kwiecień 2004.

Groot, G.-R. de. 1987. Problems of Legal translation from the Point of View of a Comparative Lawyer. in: Netherlands Reports to the Twelfth International Congress of Comparative Law. The Hague: T.M.C. Asser Institute. pp.1-19.

Groot, G.-R. de, 2006. Legal Translation. In: Smits, J.M. (Ed.), Elgar Encyclopedia of Comparative Law. Cheltenham.UK: Edward Elgar Publishing Limited. pp. 423-434.

Großfeld, B. 1996. Kernfragen der Rechtsvergleichung. in: V. Grosswald Curran (Ed.) Comparative Law: An Introduction. Durham North Carolina: Carolina Academic Press. pp. 118-122; 106-115.

Hofmański, P., et al. (Eds.) 2008. Europejski Nakaz Aresztowania w teorii i praktyce państw członkowskich Unii Europejskiej. Warszawa: Wolter Kluwer Polska Sp. z o.o.

Hofstede, G. 2001. Culture's Consequences: Comparing Values, Behaviours, Institutions and Organizations Across Nations, Thousand Oaks/London/New Delhi: Sage Publications International Educational and Professional Publisher.

Holliday, A., et al., (Eds.) 2004. Intercultural Communication: an Advanced Resource Book. London and New York: Routledge.

Jandt, F.E. 2007. An Introduction to Intercultural Communication: Identities in a Global Community. Thousand Oaks/London/New Delhi: SAGEPublications, Inc.

Jopek-Bosiacka, A. 2006. Przekład prawny i sądowy. Warszawa: Wydawnictwo Naukowe PWN.

Joseph, E. J.. 1995. Indeterminacy, Translation and the Law in Translation and the Law. In: M. Morris (Ed.) Translation and the Law. Amsterdam/Philadelphia: John Benjamins Publishing Company.

Kielar, B. 1977. Language of the Law in the Aspect of Translation. Warszawa: Wydawnictwa Uniwersytetu Warszawskiego.

Kierzkowska, D. 2002. Ttumaczenie prawnicze. Warszawa: TEPIS.

Lyons, J. 1981. Language and Linguistics: An Introduction. Cambridge: Cambridge University Press.

Mellinkoff, D., 1963. The language of the Law. Boston: Little, Brown and Company. 


\section{Grażyna Bednarek: Translation of the European Arrest \\ Warrant in the Light of Intercultural Communication}

Munday, J. 2001. Introducing Translation Studies: Theories and Applications. London and New York: Routledge

Nord, Ch. 1997. Translating as a Purposeful Activity: Functionalist Approach Explained. Manchester, UK \& Northampton MA: St. Jerome Publishing.

Nord, Ch. 2005. Text Analysis in Translation: Theory, Methodology, and Didactic Application of Model for Translation-Oriented Text Analysis" second edition. Amsterdam-New York: Rodopi B. V.

Pérignon, I., Bauc C. 2007. The European Arrest Warrant: a Growing Success Story.in: ERA Academy of European Law, No. 8: pp. 203-214.

Pisarska, A., Tomaszkiewicz T. 1996. Wspótczesne tendencje przekładoznawcze. Poznań: Wydawnictwo Naukowe Uniwersytetu Adama Mickiewicza.

Sager, J.C. 1994. Language Engineering and Translation Consequences of Automation. Amsterdam/Philadelphia: John Benjamins Publishing Company.

Sapir, E. 1966. Culture, Language and Personality. in: D.G. Mandelbaum, (Ed.): Selected Essays. Berkeley and Los Angeles: University of California Press.

Šarčević S. 1997. New Approach to Legal Translation. The Hague: Kluwer Law International.

Snell-Hornby, M. 1988. Translation Studies An Integrated Approach. Amsterdam/Philadelphia: John Benjamins Publishing Company.

Scollon R. and Wong Scollon S. 2001. Intercultural Communication A Discourse Approach Second Edition. Oxford: Blackwell Publishing.

Snell-Hornby, M. 2006. The Turns of Translation Studies New paradigms or shifting viewpoints. Amsterdam/Philadelphia: John Benjamins Publishing Company.

Tiersma, P.M. 1999. Legal Language. Chicago: University of Chicago Press.

Vermeer, H.J. 1996. A Skopos Theory of Translation (Some arguments for and against). Heildelberg: TextconText.

Wagner, E., Bech, S., and Martínez, J.M. 2002. Translating for the European Union Institutions. Manchester, UK and Northampton MA: St. Jerome Publishing.

Whorf, B. 1966. Language, Thought, and Reality. in: J.B. Carroll (Ed.) Selected Writings of Benjamin Lee Whorf. The United States of America: The Massachusetts Institute of Technology.

Zweigert, K. and Kötz, H. 1992. An Introduction to Comparative Law. Oxford: Clarendon Press. 